\title{
Unusual route for preparation of manganese(II), cobalt(II), zinc(II) and cadmium(II) carbonate compounds: synthesis and spectroscopic characterizations
}

\author{
MOAMEN S REFAT ${ }^{\dagger, *}$ and MOHSEN M AL-QAHTANI ${ }^{\dagger}$ \\ Department of Chemistry, Faculty of Science, Taif University, 888 Taif, Kingdom Saudi Arabia \\ ${ }^{\dagger}$ Department of Chemistry, Faculty of Science, Suez Canal University, Port Said 42111, Egypt
}

MS received 4 February 2010; revised 7 April 2010

\begin{abstract}
The manganese(II) carbonate, $\mathrm{MnCO}_{3} \cdot \mathrm{H}_{2} \mathrm{O}$, cobalt(II) carbonate, $\mathrm{CoCO}_{3} \cdot 4 \mathrm{H}_{2} \mathrm{O}$, zinc(II) carbonate, $\mathrm{ZnCO}_{3}$ and cadmium(II) carbonate, $\mathrm{CdCO}_{3}$, respectively, were synthesis by a new simple unusual route during the reaction of aqueous solutions of $\mathrm{MnX}_{2}, \mathrm{CoX}_{2}, \mathrm{ZnX}_{2}$ and $\mathrm{CdX}_{2}$, where $\left(\mathrm{X}=\mathrm{Br}^{-}\right.$and $\left.\mathrm{ClO}_{4}^{-}\right)$with urea at high temperature within $\sim 90^{\circ} \mathrm{C}$ for $6 \mathrm{~h}$. The infrared spectra of the reaction products clearly indicate the absence of the bands of urea, but show the characteristic bands of ionic carbonate, $\mathrm{CO}_{3}^{2-}$. A general mechanism describing the preparation of manganese(II), cobalt(II), zinc(II) and cadmium(II) carbonate compounds are discussed.
\end{abstract}

Keywords. $\mathrm{MnCO}_{3} \cdot \mathrm{H}_{2} \mathrm{O} ; \mathrm{CoCO}_{3} \cdot 4 \mathrm{H}_{2} \mathrm{O} ; \mathrm{ZnCO}_{3} ; \mathrm{CdCO}_{3} ;$ infrared spectra.

\section{Introduction}

Urea is physiologically very important. It is the chief nitrogenous product of protein metabolism. Urea has a melting point of $132^{\circ} \mathrm{C}$, soluble in water and ethanol, but insoluble in ether. Urea is used for preparing formaldehyde-urea resin (plastics) (Feldman and Barbalata 1996), barbiturates (Finar 1973), and fertilizers (Rahman et al 1994; Wang and Douglas 1996; George et al 1997; Yerokun 1997). Urea is also extensively used in the paper industry to soften cellulose and has been used to promote healing in infected wounds and many other applications in the field of medicine (Miyagawa 1986; Heinig 1996; Gnewuch and Sosnovsky 1997). For example, metal-urea complexes have a pharmaceutical application that the platinum-urea complex was recorded a significant effect as an antitumor agent (Sugimura et al 1990).

Yamaguchi and Stewart (Stewart 1957; Yamaguchi et al 1957) were assigned all of the observed frequencies in the spectra of urea and urea- $d_{4}$. The two vibrations of the frequencies at 1686 and $1603 \mathrm{~cm}^{-1}$ were assigned as the $1686 \mathrm{~cm}^{-1}$ band due to $\mathrm{CO}$ stretching vibration and the $1603 \mathrm{~cm}^{-1}$ band for $\mathrm{NH}_{2}$ bending motion. The calculations studied by Yamaguchi showed that for the band at $1686 \mathrm{~cm}^{-1}$, the contribution of the $\mathrm{NH}_{2}$ bending motion is greater than that of $\mathrm{CO}$ stretching motion. The infrared bands of urea- $d_{4}$ observed at 1245 and $1154 \mathrm{~cm}^{-1}$ are

*Author for correspondence (msrefat@yahoo.com) assigned to $\mathrm{ND}_{2}$ bending vibrations. This assignment is consistent with the observed depolarization degrees of the Raman lines. The $1464 \mathrm{~cm}^{-1}$ frequency of urea is assigned to the $\mathrm{CN}$ stretching vibration. The corresponding frequency of urea- $d_{4}$ is observed at $1490 \mathrm{~cm}^{-1}$. The $1150 \mathrm{~cm}^{-1}$ band is assigned to $\mathrm{NH}_{2}$ rocking vibrations.

The reactions between transition metal ions and urea at room temperature have been studied extensively (Schafer and Curran 1966; Barbier and Hugel 1974; Zarli et al 1976; Barbier and Hugel 1977; Srivastava and Aravindaksahn 1983). The infrared spectra of these complexes clearly indicated that urea molecule behaves as a monodentate ligand and coordinates to the metal ions through the oxygen atom and not the nitrogen atom.

The nature of the reaction products depend strongly on the type of metal ions and hence the metal salt used. The novelty in our previous studies (Nour et al 1997; Sadeek et al 2004; Refat et al 2004a, b; Refat 2004; Teleb et al 2004; Sadeek and Refat 2005; Refat and Sadeek 2005; Refat 2005; Teleb and Refat 2006) were oriented to the reaction of urea ligand with different metals such as $\mathrm{Co}(\mathrm{II}), \mathrm{Pb}(\mathrm{II}), \mathrm{Sn}(\mathrm{II}), \mathrm{Cr}(\mathrm{III}), \mathrm{Fe}(\mathrm{III}), \mathrm{Au}(\mathrm{III}), \mathrm{Sn}(\mathrm{IV})$, $\mathrm{V}(\mathrm{V})$ and $\mathrm{Mo}(\mathrm{IV})$ at high temperatures which demonstrate that the types of metal ions beside their anions have a pronounced effect on the nature of the reaction products. The published papers were trended for the reaction of urea with different metal salts at elevated temperature lead to discovering a novel method for preparation $\mathrm{PbCO}_{3}$ and $\mathrm{CoCO}_{3}$ (Refat et al 2004a), lanthanide carbonates (Refat 2004; Teleb and Refat 2006), limonite, 
$\mathrm{FeO}(\mathrm{OH})$ (Sadeek 2004), $2 \mathrm{ZnCO}_{3} \cdot 3 \mathrm{Zn}(\mathrm{OH})_{2}$ (Sadeek and Refat 2005), $\mathrm{SnOCl}_{2} \cdot 2 \mathrm{H}_{2} \mathrm{O}$ (Teleb et al 2004), $\left(\mathrm{Cr}_{2} \mathrm{O}_{3}\right.$, $\mathrm{MnO}_{2}, \mathrm{MoO}_{3}$ and $\mathrm{WO}_{3}$ ) oxides resulted from a novel oxidation reduction reaction between $\left(\mathrm{K}_{2} \mathrm{CrO}_{4}\right.$ or $\left.\mathrm{K}_{2} \mathrm{Cr}_{2} \mathrm{O}_{7}\right)$, $\mathrm{KMnO}_{4}, \mathrm{Na}_{2} \mathrm{MoO}_{4}$ and $\mathrm{Na}_{2} \mathrm{WO}_{4}$, respectively, with urea in an aqueous solution at $\sim 85^{\circ} \mathrm{C}$ (Teleb and Refat 2006).

The present study was undertaken to detect the nature of the reaction products obtained during the reaction of urea with $\mathrm{MnX}_{2}, \mathrm{CoX}_{2}, \mathrm{ZnX}_{2}$ and $\mathrm{CdX}_{2}\left(\mathrm{X}=\mathrm{Br}^{-}\right.$and $\mathrm{ClO}_{4}^{-}$) with urea at $\sim 90^{\circ} \mathrm{C}$ for $6 \mathrm{~h}$ in aqueous media. The reaction products were isolated as solids and characterized by elemental analysis, infrared spectroscopy.

\section{Experimental}

All chemicals used throughout this work were Analar or extra pure grade. $\mathrm{MCO}_{3} \cdot n \mathrm{H}_{2} \mathrm{O}(\mathrm{M}=\mathrm{Mn}(\mathrm{II}), \mathrm{Co}(\mathrm{II})$, $\mathrm{Zn}(\mathrm{II})$ or $\mathrm{Cd}(\mathrm{II}) ; n=1$ for $\mathrm{MnCO}_{3}$ or $n=4$ for $\mathrm{CoCO}_{3}$ ) were prepared by mixing an aqueous solutions $(75 \mathrm{ml})$ of $0.1 \mathrm{M}$ of urea with $0.01 \mathrm{M}$ of the respective $\mathrm{Mn}$ (II), $\mathrm{Co}(\mathrm{II}), \mathrm{Zn}(\mathrm{II})$ or $\mathrm{Cd}(\mathrm{II})$ salts. The acidic radical for all starting salts is $\mathrm{MnX}_{2} \cdot n \mathrm{H}_{2} \mathrm{O}\left(\mathrm{X}=\mathrm{Br}^{-}\right.$and $\mathrm{ClO}_{4}^{-}, n=4$ or 6), $\mathrm{CoX}_{2} \cdot n \mathrm{H}_{2} \mathrm{O}\left(\mathrm{X}=\mathrm{Br}^{-}\right.$and $\mathrm{ClO}_{4}^{-}, n=x \mathrm{H}_{2} \mathrm{O}$ or 6$)$, $\mathrm{ZnX}_{2} \cdot n \mathrm{H}_{2} \mathrm{O}\left(\mathrm{X}=\mathrm{Br}^{-}\right.$and $\mathrm{ClO}_{4}^{-}, n=2$ or 6$)$ and cadmium(II) salts, $\mathrm{CdX}_{2} \cdot \mathrm{nH}_{2} \mathrm{O}\left(\mathrm{X}=\mathrm{Br}^{-}\right.$and $\mathrm{ClO}_{4}^{-}, n=4$ or $x \mathrm{H}_{2} \mathrm{O}$ ). The mixtures were heated at $\sim 90^{\circ} \mathrm{C}$ for $6 \mathrm{~h}$ in a water bath. The solid compounds were filtered off, washed several times with hot water, dried at $80^{\circ} \mathrm{C}$ in an oven for $3 \mathrm{~h}$ and then placed in vacuo over silica gel. The yields of the obtained $\mathrm{Mn}(\mathrm{II}), \mathrm{Co}(\mathrm{II}), \mathrm{Zn}(\mathrm{II})$ and $\mathrm{Cd}(\mathrm{II})$ carbonates were varied in the range $70-80 \%$ depending upon the type of metal as well as on the counter ions associated with the metal ion. The average of elemental analysis for $\mathrm{MCO}_{3} \cdot n \mathrm{H}_{2} \mathrm{O}(\mathrm{M}=\mathrm{Mn}(\mathrm{II}), \mathrm{Co}(\mathrm{II}), \mathrm{Zn}(\mathrm{II})$ and $\mathrm{Cd}(\mathrm{II})$ ) obtained during the reaction of urea with the respective metal salts almost the same and indicate the absence of nitrogen element. Analysis of the solid products obtained as follows

$$
\begin{aligned}
& \mathrm{MnCO}_{3} \cdot \mathrm{H}_{2} \mathrm{O}\left(M_{\mathrm{wt}}=132 \cdot 95\right) \\
& \text { Found }\left(\mathrm{C}=8 \cdot 95 \%, \mathrm{H}=1 \cdot 44 \%, \mathrm{Mn}=41 \cdot 22 \%, \mathrm{CO}_{3}^{2-}=\right. \\
& 45 \cdot 05 \%) . \\
& \text { Calcd }\left(\mathrm{C}=9 \cdot 02 \%, \mathrm{H}=1 \cdot 50 \%, \mathrm{Mn}=41 \cdot 32 \%, \mathrm{CO}_{3}^{2-}=\right. \\
& 45 \cdot 13 \%) . \mathrm{CoCO}_{3} \cdot 4 \mathrm{H}_{2} \mathrm{O}\left(M_{\mathrm{wt}}=190 \cdot 94\right) . \\
& \text { Found }\left(\mathrm{C}=6 \cdot 17 \%, \mathrm{H}=4 \cdot 10 \%, \mathrm{Co}=30 \cdot 45 \%, \mathrm{CO}_{3}^{2-}=\right. \\
& 31 \cdot 11 \%) . \\
& \text { Calcd }\left(\mathrm{C}=6 \cdot 28 \%, \mathrm{H}=4 \cdot 19 \%, \mathrm{Co}=30 \cdot 86 \%, \mathrm{CO}_{3}^{2-}=\right. \\
& 31 \cdot 42 \%) . \mathrm{ZnCO}_{3}\left(M_{\mathrm{wt}}=125 \cdot 38\right) . \\
& \text { Found }\left(\mathrm{C}=9 \cdot 48 \%, \mathrm{Zn}=52 \cdot 08 \%, \mathrm{CO}_{3}^{2-}=47 \cdot 77 \%\right) . \\
& \text { Calcd }\left(\mathrm{C}=9 \cdot 57 \%, \quad \mathrm{Zn}=52 \cdot 14 \%, \mathrm{CO}_{3}^{2-}=47 \cdot 85 \%\right) \text {, } \\
& \text { CdCO}\left(M_{\mathrm{wt}}=172 \cdot 42\right) . \\
& \text { Found }\left(\mathrm{C}=6 \cdot 89 \%, \mathrm{Cd}=65 \cdot 11 \%, \mathrm{CO}_{3}^{2-}=34 \cdot 62 \%\right) . \\
& \text { Calcd }\left(\mathrm{C}=6 \cdot 96 \%, \mathrm{Cd}=65 \cdot 19 \%, \mathrm{CO}_{3}^{2-}=34.80 \%\right) .
\end{aligned}
$$

Carbonate content in the four compounds were determined by dissolving a sample of each product in excess standard $\mathrm{HCl}$ and the excess of $\mathrm{HCl}$ was determined using standard sodium carbonate (Vogel 1987). The percentage of manganese, cobalt, zinc and cadmium in the compounds were determined by gravimetrical method till constant weight and stable formula. The infrared spectra of urea, all reactants and products were recorded in $\mathrm{KBr}$ discs using a Shimadzu FT-IR spectrophotometer.

\section{Results and discussion}

The reaction of aqueous solutions of urea with perchlorate and bromide salts of manganese(II), cobalt(II), zinc(II) and cadmium(II) at $c a . \sim 90^{\circ} \mathrm{C}$ produces a brown, red, white solid crystalline products, respectively. The infrared spectra of urea as well as the reaction products of different manganese(II), cobalt(II), zinc(II) and cadmium(II) salts with urea at high temperature are obtained from $\mathrm{KBr}$ discs. These spectra are shown in figure la-e. The band assignments for the products are given in table 1 . The infrared spectra show no bands due to any of the reactants and of coordinated urea, but instead, a group of bands characteristic for the ionic carbonate, $\left(\mathrm{CO}_{3}\right)^{2-}$, is appeared (Nakamoto 1978). Based on this fact, along with that obtained from elemental analysis data as well as the volumetric determination of $\left(\mathrm{CO}_{3}\right)^{2-}$ group with standard solution of $\mathrm{HCl}$; beside that the infrared spectra of the commercially obtained $\mathrm{MnCO}_{3} \cdot n \mathrm{H}_{2} \mathrm{O}, \mathrm{CoCO}_{3}$. $n \mathrm{H}_{2} \mathrm{O}, \mathrm{ZnCO}_{3}$ and $\mathrm{CdCO}_{3}$ are the same as that of the reaction products. The products obtained were identified as $\mathrm{MnCO}_{3} \cdot \mathrm{H}_{2} \mathrm{O}, \mathrm{CoCO}_{3} \cdot 4 \mathrm{H}_{2} \mathrm{O}, \mathrm{ZnCO}_{3}$ and $\mathrm{CdCO}_{3}$. The infrared assignments agree quite well with those known (Nakamoto 1978) for the ionic carbonate $\left(\mathrm{CO}_{3}\right)^{2-}$.

Previous studies (Nour et al 1997; Sadeek et al 2004; Refat et al 2004a, b; Refat 2004; Teleb et al 2004; Sadeek and Refat 2005; Refat and Sadeek 2005; Refat 2005; Teleb and Refat 2006) indicated that the nature of the reaction product obtained from the reaction of metal ions with urea at high temperature depends on the type of metal ion, and in some cases on the nature of the metal salts used.

At room temperature the coordination compounds of manganese(II) ion with urea have been studied extensively (Antonienko and Nuger 1966; Stancheva 1970; Barbier and Hugel 1974; Yamagata et al 1989) and it was found that urea coordinates to $\mathrm{Mn}$ (II) ions at room temperature via its oxygen atom, forming the $\left[\mathrm{Mn}(\text { urea })_{4}\right] \mathrm{X}_{2}$ octahedral complex (Barbier and Hugel 1974). However, The Mn(II)-urea compounds of the type $\mathrm{Mn}(\text { urea })_{6} \mathrm{X}_{2}$ $\left(\mathrm{X}=\mathrm{Br}^{-}, \mathrm{I}^{-}\right.$, and $\left.\mathrm{ClO}_{4}^{-}\right)$are also known. They are of ionic nature and could be written as $\left[\mathrm{Mn}(\text { urea })_{6}\right] \mathrm{X}_{2}$. These compounds are of high-spin octahedral structure with urea coordinated to manganese through its oxygen atom. At high temperature the role of $\mathrm{Mn}$ (II) ions in decomposing 

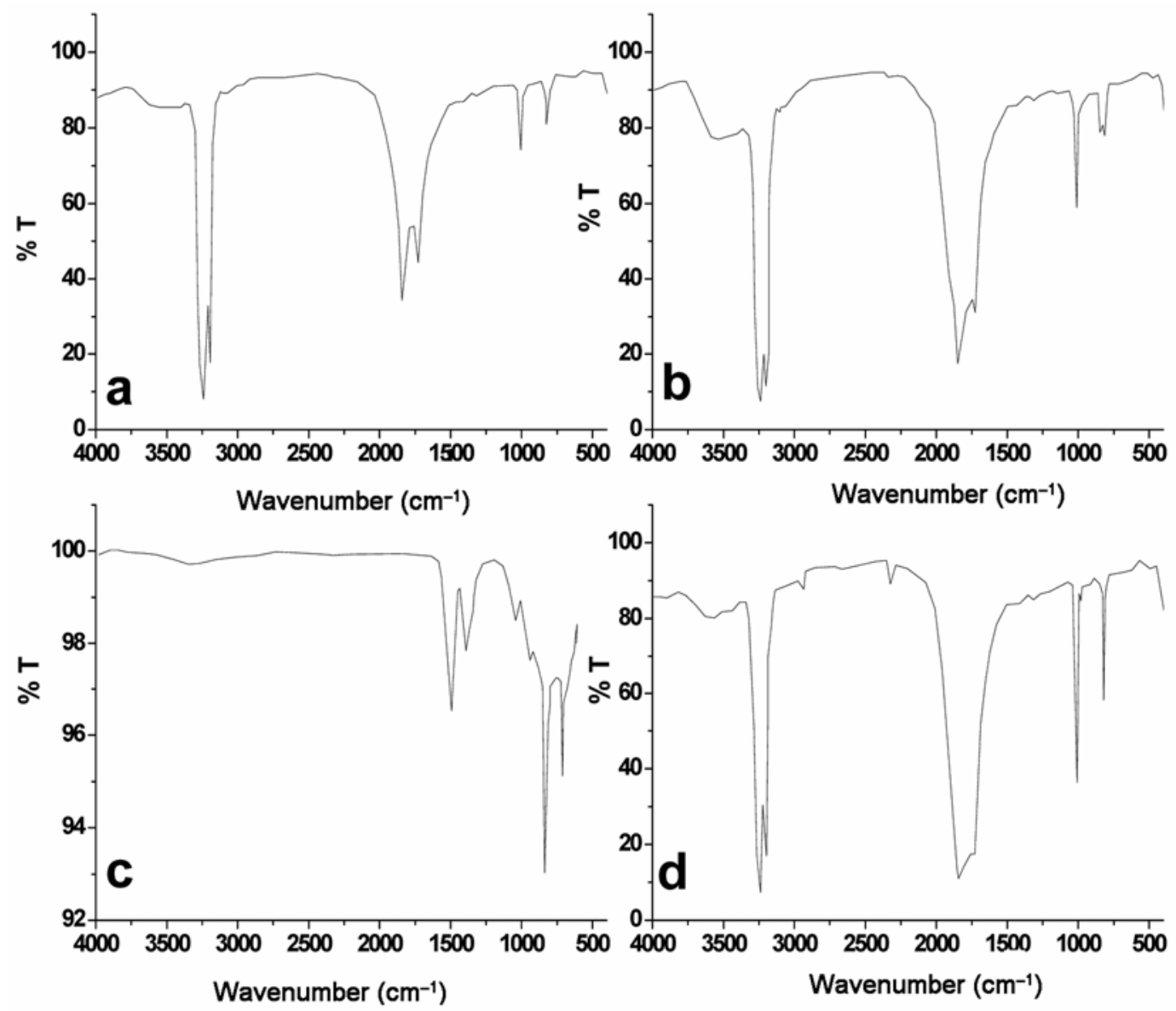

Figure 1. Infrared spectra of the products obtained from the reaction of (a) $\mathrm{MnX}_{2}$, (b) $\operatorname{CoX}$, (c) $\mathrm{ZnX}_{2}$ and (d) $\mathrm{CdX}_{2}$ where $\left(\mathrm{X}=\mathrm{Br}^{-}\right.$and $\left.\mathrm{ClO}_{4}^{-}\right)$with urea at high temperature.

the coordinated urea in the form of $\left[\mathrm{Mn}(\text { urea })_{4}\right] \mathrm{X}_{2}$ or $\left[\mathrm{Mn}\right.$ (urea) $\left.{ }_{6}\right] \mathrm{X}_{2}$ could be understood according to the following reactions

(i) $\left[\mathrm{Mn}(\text { urea })_{4}\right] \mathrm{X}_{2}+6 \mathrm{H}_{2} \mathrm{O} \stackrel{90^{\circ} \mathrm{C}}{\longrightarrow}$

$\mathrm{MnCO}_{3} \cdot \mathrm{H}_{2} \mathrm{O}+3 \mathrm{CO}_{2}+2 \mathrm{NH}_{4} \mathrm{X}+6 \mathrm{NH}_{3}$

$\left(\mathrm{X}=\mathrm{ClO}_{4}^{-}\right.$or $\left.\mathrm{Br}^{-}\right)$

(ii) $\left[\mathrm{Mn}(\text { urea })_{6}\right] \mathrm{X}_{2}+8 \mathrm{H}_{2} \mathrm{O} \stackrel{90^{\circ} \mathrm{C}}{\longrightarrow}$

$\mathrm{MnCO}_{3} \cdot \mathrm{H}_{2} \mathrm{O}+5 \mathrm{CO}_{2}+2 \mathrm{NH}_{4} \mathrm{X}+10 \mathrm{NH}_{3}$

$\left(\mathrm{X}=\mathrm{Br}^{-}\right.$and $\left.\mathrm{ClO}_{4}^{-}\right)$

The X-ray studies on cobalt(II) salt-urea complexes (Galdecki and Golinski 1961; Kuznetsov et al 1967; Rau et al 1971) indicated that the $\mathrm{Co}\left(\mathrm{NO}_{3}\right)_{2}$ reacts with urea at room temperature to form the complex [Co(urea $\left.)_{4}\right]$ $\left(\mathrm{NO}_{3}\right)_{2}$; in these complexes urea coordinates to $\mathrm{Co}(\mathrm{II})$ via its oxygen atom. The role of $\mathrm{Co}$ (II) ions in decomposing the coordinated urea at high temperature may be understood as follows

$$
\begin{aligned}
& \left.[\text { Co(urea) })_{4}\right] \mathrm{X}_{2}+9 \mathrm{H}_{2} \mathrm{O} \stackrel{90^{\circ} \mathrm{C}}{\longrightarrow} \\
& \mathrm{CoCO}_{3} \cdot 4 \mathrm{H}_{2} \mathrm{O}+3 \mathrm{CO}_{2}+6 \mathrm{NH}_{3}+2 \mathrm{NH}_{4} \mathrm{X}
\end{aligned}
$$$$
\left(\mathrm{X}=\mathrm{ClO}_{4}^{-} \text {or } \mathrm{Br}^{-}\right) \text {. }
$$

At room temperature the coordination compounds of zinc(II) ion with urea have been studied extensively (Penland et al 1957; Yar and Lessinger 1995) and it was found that, in these complexes, urea coordinated through its oxygen atom forming the $\left[\mathrm{Zn}(\text { urea })_{2} \mathrm{X}_{2}\right]$ where $\left(\mathrm{X}=\mathrm{Cl}^{-}, \mathrm{NO}_{3}^{-}\right.$or $\left.\mathrm{CH}_{3} \mathrm{COO}^{-}\right)$. At high temperature the role of $\mathrm{Zn}$ (II) ions in decomposing the coordination urea in the form of $\left[\mathrm{Zn}(\text { urea })_{2} \mathrm{X}_{2}\right]$ could be understood as follows

$$
\begin{gathered}
{\left[\mathrm{Zn}(\text { urea })_{2} \mathrm{X}_{2}\right]+3 \mathrm{H}_{2} \mathrm{O} \stackrel{90^{\circ} \mathrm{C}}{\longrightarrow}} \\
\mathrm{ZnCO}_{3}+\mathrm{CO}_{2}+2 \mathrm{NH}_{4} \mathrm{X}+2 \mathrm{NH}_{3} \\
\left(\mathrm{X}=\mathrm{ClO}_{4}^{-} \text {or } \mathrm{Br}^{-}\right)
\end{gathered}
$$

Adducts of $\mathrm{ZnX}_{2} \cdot 2$ urea $(\mathrm{X}=\mathrm{Cl}, \mathrm{Br}, \mathrm{I}), \mathrm{CdX}_{2} \cdot 2$ urea $(\mathrm{X}=\mathrm{Br}, \mathrm{I}), \mathrm{CdX}_{2} \cdot$ urea $(\mathrm{X}=\mathrm{Cl}, \mathrm{Br}, \mathrm{I})$ and $\mathrm{HgX}_{2} \cdot$ urea 
Table 1. Infrared frequencies $\left(\mathrm{cm}^{-1}\right)$ and assignments of the products obtained from the reaction of (a) $\mathrm{MnX}_{2}$, (b) $\mathrm{CoX}_{2}$, (c) $\mathrm{ZnX}_{2}$ and (d) $\mathrm{CdX}_{2}$, where $\left(\mathrm{X}=\mathrm{Br}^{-}\right.$and $\left.\mathrm{ClO}_{4}^{-}\right)$with urea at high temperature.

\begin{tabular}{lllll}
\hline \multicolumn{4}{c}{ Frequencies* $\left(\mathrm{cm}^{-1}\right)$} & \\
\cline { 1 - 4 }$a$ & \multicolumn{1}{c}{$b$} & \multicolumn{1}{c}{$c$} & \multicolumn{1}{c}{$d$} & Assignments \\
\hline 2964,2925 & 2924 & - & 3070,2954 & $v(\mathrm{O}-\mathrm{H}) ; \mathrm{H}_{2} \mathrm{O}$ \\
1463,1376 & 1464,1378 & 1503,1391 & 1468 & $v(\mathrm{C}-\mathrm{O}) ; \mathrm{CO}_{3}^{2-}$ \\
1070 & 1079 & 1060 & 1077 & \\
863 & 866 & 833 & 860,836 & $\delta(\mathrm{OCO}) ; \mathrm{CO}_{3}^{2-}$ \\
726 & $724,732,722$ & 708 & 723 & \\
\hline
\end{tabular}

*br, broad; $m$, medium; sh, shoulder; $s$, strong; $w$, weak; $v$, stretching; $\delta$, bending

$(\mathrm{X}=\mathrm{Cl}, \mathrm{Br}$ ) have been characterized (Maria and Santos 1988). The shifts of the stretching vibrations to low frequency $(v \mathrm{CO})$ and to high frequencies $(v \mathrm{CN}$ and $v \mathrm{NH})$ indicated that urea is oxygen-bonded to the metals.

At high temperature the role of $\mathrm{Cd}(\mathrm{II})$ ions in decomposing the coordination urea in the form of $\left[\mathrm{Cd}(\text { urea })_{2} \mathrm{X}_{2}\right]$ could be understood as follows

$$
\begin{aligned}
& {\left[\mathrm{Cd}(\text { urea })_{2} \mathrm{X}_{2}\right]+3 \mathrm{H}_{2} \mathrm{O} \stackrel{90^{\circ} \mathrm{C}}{\longrightarrow}} \\
& \mathrm{CdCO}_{3}+\mathrm{CO}_{2}+2 \mathrm{NH}_{4} \mathrm{X}+2 \mathrm{NH}_{3} \\
& \left(\mathrm{X}=\mathrm{ClO}_{4}^{-} \text {or } \mathrm{Br}^{-}\right) .
\end{aligned}
$$

The $\left(\mathrm{CO}_{3}\right)^{2-}$ ion is planar and therefore, belongs to the $\mathrm{D}_{3 \mathrm{~h}}$ symmetry. It is expected to display four modes of vibrations, $\mathrm{A}_{1}^{\prime}+\mathrm{A}_{2}^{\prime \prime}+2 E^{\prime} \quad\left(E^{\prime}\right.$ is a double degenerate motion). The vibration $\mathrm{A}_{1}^{\prime}$ is only Raman active while the other $v_{2}, v_{3}$ and $v_{4}$ are infrared active. The stretching vibrations of the type $v(\mathrm{C}-\mathrm{O}), v_{3}\left(\mathrm{E}^{\prime}\right)$ is observed as a strong broad band in the range of $1503-1376 \mathrm{~cm}^{-1}$ while the stretching vibration $v(\mathrm{C}-\mathrm{O}), v_{1}\left(\mathrm{~A}_{1}^{\prime}\right)$ is observed in the region $\sim 1070 \mathrm{~cm}^{-1}$ as a medium-to-weak band. It should be indicated here that this motion $\left(\mathrm{A}_{1}^{\prime}\right)$ should be infrared inactive, its weak appearance in the spectrum of $\mathrm{MCO}_{3}$. $n \mathrm{H}_{2} \mathrm{O}$ could be related to weak solid-solid interactions which causes the symmetry of $\mathrm{CO}_{3}^{2-}$ to be lowered than $\mathrm{D}_{3 \mathrm{~h}}$. The out of plane of vibration $\delta(\mathrm{OCO}), v_{2}\left(\mathrm{~A}_{2}^{\prime \prime}\right)$ is observed in the range of $\sim 860 \mathrm{~cm}^{-1}$ as a strong band, while the angle deformation bending vibration $\delta(\mathrm{OCO})$, $v_{4}\left(E^{\prime}\right)$ appear in the range of $744-708 \mathrm{~cm}^{-1}$ as a medium strong. The infrared spectra of metal(II) carbonate, $\mathrm{MCO}_{3} \cdot n \mathrm{H}_{2} \mathrm{O}$ show that some of these products clearly have an uncoordinated water. The band related to the stretching vibration $v(\mathrm{O}-\mathrm{H})$ of uncoordinated $\mathrm{H}_{2} \mathrm{O}$ is observed as expected in the range of $\sim 3000 \mathrm{~cm}^{-1}$ (table 1).

\section{References}

Antonienko N S and Nuger J A 1966 Z. Neorg. Chim. 11 1072

Barbier J P and Hugel R 1974 Inorg. Chim. Acta 1093

Barbier J P and Hugel R P 1977 J. Inorg. Nucl. Chem. 392283
Feldman D and Barbalata A 1996 Synthetic polymers (London: Chapman \& Hall)

Finar I L 1973 Organic chemistry (London: Longman Group Limited) p 460

Galdecki Z and Golinski B 1961 Zeszyty Nauk. Politech. Lodz. Chem. 1015

George S, Chellapandian M, Sivasankar B and Jayaraman K 1997 Bioprocess Eng. 1683

Gnewuch C T and Sosnovsky G 1997 Chem. Rev. 97829

Heinig R 1996 SOFW J. 122998

Kuznetsov V G, Kondrat'eva N G and Druzhinin I G 1967 Russ. J. Inorg. Chem. 12665

Maria R M C and Santos C A 1988 Thermochim. Acta 125295

Miyagawa C I 1986 Drug Intell. \& Clin. Pharma. 20527

Nakamoto K 1978 Infrared and Raman spectra of inorganic and coordination compounds (New York: Wiley Interscience) 3rd edn.

Nour E M, Teleb S M, Al-Khososy N A and Refat M S 1997 Synth. React. Inorg. Met-Org. Chem. 27505

Penland R B, Mizushima S, Curran C and Quagliano J V 1957 J. Am. Chem. Soc. 791575

Rahman M J, Bozadjiev P and Polovski Y 1994 Fert. Res. 38 89

Rau T F, Kurkutova E N, Kondrat'eva N G and Kinderov A P 1971 Russ. J. Inorg. Chem. 16933

Refat M S 2004 Synth. React. Inorg. Met.-Org. Chem. 341605

Refat M S and Sadeek S A 2005 Latvian J. Chem. 4343

Refat M S, Sadeek S A and Nasr D E 2005 Bull. Chem. Technolog. Maced. 24153

Refat M S, Teleb S M and Sadeek S A 2004a Spectrochim. Acta A60 2803

Refat M S, Sadeek S A and Teleb S M 2004b J. Argen. Chem. Soc. 9223

Sadeek S A and Refat M S 2005 J. Coord. Chem. 581727

Sadeek S A, Refat M S and Teleb S M 2004 J. Korea, Chem. Soc. 48358

Schafer M and Curran C 1966 Inorg. Chem. 5256

Srivastava P C and Aravindaksahn C 1983 Z. Phys. Chem. Leipzig 26461

Stancheva P 1970 Nauch. Tr. Vissk. Pedagog. Inst. Plovdiv 8 103

Stewart J E 1957 J. Chem. Phys. 26248

Sugimura M, Kameyama Y, Hashimoto T, Kobayashi T and Muramatsu S 1990 Chem. Abs. 11263

Teleb S M and Refat M S 2006 Bull. Chem. Technolog. Maced. 2557 
Preparation of manganese(II), cobalt(II), zinc(II) and cadmium(II) carbonate compounds

Teleb S M, Refat M S, Sadeek S A 2004 Ukrainian Chem. J. 68 35

Vogel 1987 Qualitative inorganic analysis (New York: John Wiley \& Sons, Inc)

Wang X J and Douglas L A 1996 Agrochimica 40209

Yamagata K, Saito Y and Abe T 1989 J. Phys. Soc. Jpn. 58 752
Yamaguchi A, Miyazawa T, Shimanouchi T and Mizushima S 1957 Spectrochim. Acta 10170

Yar O and Lessinger L 1995 Acta Cryst. Sect. C Cryst. Struct. Commun. C51 2282

Yerokun O A 1997 S. Afr. J. Plant Soil 1463

Zarli B, Dall'Olio G and Sindellari L 1976 J. Inorg. Nucl. Chem. 38491 